Article

\title{
Acai Extract Transiently Upregulates Erythropoietin by Inducing a Renal Hypoxic Condition in Mice
}

\author{
Shuichi Shibuya ${ }^{1,2}$, Toshihiko Toda ${ }^{2}$, Yusuke Ozawa ${ }^{2}$, Mario Jose Villegas Yata ${ }^{3}$ and \\ Takahiko Shimizu 1,2,*(D) \\ 1 Aging Stress Response Research Project Team, National Center for Geriatrics and Gerontology, \\ 7-430 Morioka-cho, Obu, Aichi 474-8511, Japan; s-shibuya@ncgg.go.jp \\ 2 Department of Endocrinology, Hematology and Gerontology, Chiba University Graduate School of \\ Medicine, 1-8-1 Inohana, Chuo-ku, Chiba 260-8670, Japan; hik_toda-jac@proteome.jp (T.T.); \\ ozawayusuke3@gmail.com (Y.O.) \\ 3 FRUTA FRUTA, Inc., 3-3 Kandajimbo-cho, Chiyoda-ku, Tokyo 101-0051, Japan; mario@frutafruta.com \\ * Correspondence: shimizut@ncgg.go.jp; Tel.: +81-562-44-5651; Fax: +81-562-48-2373
}

Received: 18 January 2020; Accepted: 17 February 2020; Published: 19 February 2020

\begin{abstract}
Acai (Euterpe oleracea Mart. Palmae, Arecaceae) is a palm plant native to the Brazilian Amazon. It contains many nutrients, such as polyphenols, iron, vitamin E, and unsaturated fatty acids, so in recent years, many of the antioxidant and anti-inflammatory effects of acai have been reported. However, the effects of acai on hematopoiesis have not been investigated yet. In the present study, we administered acai extract to mice and evaluated its hematopoietic effects. Acai treatment significantly increased the erythrocytes, hemoglobin, and hematocrit contents compared to controls for four days. Then, we examined the hematopoietic-related markers following a single injection. Acai administration significantly increased the levels of the hematopoietic-related hormone erythropoietin in blood compared to controls and also transiently upregulated the gene expression of Epo in the kidney. Furthermore, in the mice treated with acai extract, the kidneys were positively stained with the hypoxic probe pimonidazole in comparison to the controls. These results demonstrated that acai increases the erythropoietin expression via hypoxic action in the kidney. Acai can be expected to improve motility through hematopoiesis.
\end{abstract}

Keywords: acai; erythropoiesis; erythropoietin

\section{Introduction}

To maintain oxygen homeostasis, mammals have hematopoietic regulatory mechanisms, including erythropoiesis. Erythropoietin (EPO) is a hematological factor mainly expressed in the kidney in adults [1]. EPO is induced under conditions of reduced oxygen levels, as well as blood loss [2]. The Epo transcription is regulated by hypoxia-inducible transcription factors (HIFs), which have two oxygen-responsive sites associated with prolyl hydroxylase and lead to degradation by ubiquitination under normoxia [3]. This evidence demonstrates that the redox states on renal proteins containing HIF are potential indicators of erythropoiesis in adult mammals.

Acai (Euterpe oleracea Mart. Palmae, Arecaceae) is a large palm plant found in the northern region of South America, called the "Amazon", in Brazil. Acai berries have a high polyphenol content, including anthocyanins, such as cyanidine-3-glucoside (C3Glc), cyanidine-3-diglucoside, and cyanidin-3-rutinoside, which contribute to antioxidant activity [4]. In several rodent studies, the benefits of acai intervention have been reported to include improving cardiac dysfunction following myocardial infarction [5], protection from diet-induced obesity [6] and hepatic steatosis [7], prevention of brain oxidative damage [8], and modulation of age-related hippocampal inflammation [9]. Acai intake is 
also expected to be a useful therapeutic strategy for chronic kidney disease with oxidative stress, inflammation, and dysbiosis [10]. However, no studies have determined the erythropoietic effect of acai on renal redox alteration.

In the present study, in order to clarify the erythropoietic action of acai, we administered acai extract to mice and examined the relationship between the erythropoietic factors and the redox change in the kidney.

\section{Materials and Methods}

\subsection{Animals}

C57BL/6NCrSlc mice were purchased from Japan SLC (Shizuoka, Japan) and inbred in our own cohorts. The animals were housed under a 12-h light/dark cycle and fed an MF diet (Oriental Yeast Co., Ltd., Tokyo, Japan) ad libitum. The mice were maintained and studied according to the protocols approved by the Animal Care Committee of the Chiba University.

\subsection{Administration}

Acai extract (Table 1, Lot. 171115 and 180622) provided by FRUTA FRUTA, Inc. (Tokyo, Japan) was made by finely grinding whole fruit and filtrating with a \#30 strainer. The extract was orally administered at $10 \mathrm{~mL} / \mathrm{kg} /$ day via gavage to mice 1 time $(n=8)$ and for four days $(n=4)$ at $12-16$ weeks of age. C3Glc (NS380102) was purchased from Nagara Science (Gifu, Japan). ASP1517 (roxadustat, \#15294) was purchased from Cayman Chemical (Ann Arbor, MI, USA). The water-dissolved C3Glc $(50 \mathrm{mg} / \mathrm{kg}, n=6)$ and $0.5 \%$ carboxymethyl cellulose-suspended ASP1517 (80 mg/kg, $n=7)$ were administered orally once to littermate mice of the acai-treated cohort. The study was performed using the blood and kidney tissue of animals collected under anesthesia 2-3 $\mathrm{h}$ after the final administration.

Table 1. Contents in $100 \mathrm{~g}$ of acai extract.

\begin{tabular}{cccc}
\hline Contents & Fatty Acids & (\%) \\
\hline Energy intake & $82.0 \mathrm{kcal}$ & Palmitic acid (C16:0) & 22.5 \\
Protein & $1.4 \mathrm{~g}$ & Palmitoleic acid (C16:1) & 3.3 \\
Total lipids & $6.9 \mathrm{~g}$ & Stearic acid (C18:0) & 1.9 \\
Carbohydrates & $2.0 \mathrm{~g}$ & Oleic acid (C18:1) & 61.2 \\
Dietary fiber & $3.3 \mathrm{~g}$ & Linoleic acid (C18:2) & 10.6 \\
Total polyphenols & $390 \mathrm{mg}$ & Linolenic acid (C18:3) & 0.5 \\
Iron & $1.0 \mathrm{mg}$ & & \\
\hline
\end{tabular}

\subsection{Histology}

To evaluate the tissue hypoxic area, Hypoxyprobe ${ }^{\mathrm{TM}}-1$ Omni (Hypoxyprobe, Inc., Burlington, MA, USA) was used [11]. Mice were sacrificed $15 \mathrm{~min}$ after being intraperitoneally injected with anesthetic and $60 \mathrm{mg} / \mathrm{kg}$ of pimonidazole. The kidney was fixed in a $4 \%$ paraformaldehyde phosphate buffered saline (PBS) (Nacalai Tesque, Inc., Kyoto, Japan) and embedded in paraffin. The rehydrated sections were antigen retrieved with $10 \mathrm{mM}$ citrate buffer ( $\mathrm{pH} 6.0$, with $0.05 \%$ Tween 20) at $95{ }^{\circ} \mathrm{C}$ for $30 \mathrm{~min}$, washed with PBS containing $0.1 \%$ Tween 20 three times, and intrinsic peroxidases were quenched with $3 \% \mathrm{H}_{2} \mathrm{O}_{2}$ for $30 \mathrm{~min}$. We performed blocking with $3 \%$ goat serum or Blocking One Histo (Nacalai Tesque) and then treated samples with 1:200 or 1:20 diluted anti-pimonidazole antibody (Hypoxyprobe, Inc.). The pimonidazole-positive area was evaluated by the QWin V3 imaging software program (Leica, Wetzlar, Germany) or a BZ-X710 analyzer (Olympus Co., Tokyo, Japan) using the ABC staining kit (Vector Labs., Inc., Burlingame, CA, USA) or the FITC-fluorescence method (goat anti-rabbit antibody \#AP307F, Sigma (St. Louis, MO, USA) and Fluoro-KEEPER Antifade Reagent with DAPI \#12745-74; Nacalai Tesque), respectively. 


\subsection{Measurement of EPO}

The plasma EPO level was measured using the Mouse Erythropoietin Quantikine ELISA kit (\#MEP00B; R\&D Systems, Inc., Minneapolis, MN, USA) according to the manufacturer's instructions. In brief, thawed plasma was diluted 2-fold by calibrator diluents and then incubated on an antibody-coated microplate with each volume of assay diluents for $2 \mathrm{~h}$ using an orbital shaker. Washed wells were treated with antiserum conjugate for $2 \mathrm{~h}$ and with a substrate mixture for $30 \mathrm{~min}$. The optical density measured at 450 and $540 \mathrm{~nm}$ was analyzed with the standards curve using the 4-parameter logistic curve-fit.

\subsection{Quantitative Polymerase Chain Reaction (PCR)}

Total RNA was extracted from the kidney using the RNAlater (Thermo Fisher Scientific, Waltham, MA, USA) and the Sepasol-RNA I Super G reagent (Nacalai Tesque) according to the manufacturer's instructions. The cDNA was synthesized from $1 \mathrm{mg}$ total RNA using ReverTra Ace qPCR RT Master Mix (Toyobo, Osaka, Japan). Real-time PCR was performed with the SsoAdvanced SYBR Green Supermix (Bio-Rad, Hercules, CA, USA) on a Mini-Opticon (Bio-Rad) according to the manufacturer's protocols. All data were normalized to the level of the housekeeping gene $\beta$-Actin/Actb. The following primers were used for the analysis: Actb, forward, 5'-GCC CTA GGC ACC AGG GTG TGA-3' , and reverse, 5' -TCC TCA GGG GCC ACA CGC A-3'; Epo, forward, 5' -TCA TCT GCG ACA GTC GAG TTC TG-3' ${ }^{\prime}$, and reverse, $5^{\prime}$-GGT ATC TGG AGG CGA CAT CAA TTC- $3^{\prime}$; and Vegfa, forward, $5^{\prime}$-GCA GCT TGA GTT AAA CGA ACG-3' , and reverse, 5' $^{\prime}$-GGT TCC CGA AAC CCT GAG-3' .

\subsection{Hematological Cytometry}

The number of red blood cells and leukocytes, hemoglobin levels, and hematocrit levels were measured by the Oriental Yeast hematology analyzing service (Tokyo, Japan).

\subsection{Statistical Analyses}

The statistical analyses were performed using the Student's $t$-test for comparisons between two groups and a one-way analysis of variance/Tukey's test for comparisons of three or more groups. Differences between the data were considered significant when the p-values were less than 0.05 . All data are expressed as the mean \pm standard deviation (SD).

\section{Results}

\subsection{Acai Extract Alters Hematological Parameters}

First, to investigate the hematological effects, we administered acai extract and measured the hematological parameters in mice. Treatment with acai extract significantly increased the erythrocyte content (RBC), hemoglobin level (HGB), and hematocrit level (HCT) but not the leukocyte content (WBC) or reticulocyte count (RET) in blood for four days (Table 2). Acai extract also induced no significant change in the erythrocyte mean cell volume (MCV), mean cell hemoglobin (MCH), mean cell hemoglobin concentration (MCHC), or platelet content (PLT) (Table 2). These results suggest that acai induced a hemopoietic effect or suppressed red blood cell degradation. 
Table 2. Effect of acai extract on the hematological parameters in mice $(n=4)$.

\begin{tabular}{ccc}
\hline & Control & $\mathbf{1 0} \mathbf{g} / \mathbf{k g}$ of Acai for Four Days \\
\hline WBC $(/ \mu \mathrm{L})$ & $2500 \pm 804$ & $2275 \pm 660$ \\
$\mathrm{RBC}\left(\times 10^{4} / \mu \mathrm{L}\right)$ & $876 \pm 11$ & $931 \pm 12^{*}$ \\
$\mathrm{HGB}(\mathrm{g} / \mathrm{dL})$ & $14.1 \pm 0.5$ & $14.9 \pm 0.4^{*}$ \\
$\mathrm{HCT}(\%)$ & $47.6 \pm 0.6$ & $51.1 \pm 1.4^{*}$ \\
$\mathrm{MCV}(\mathrm{fL})$ & $54.4 \pm 0.7$ & $54.9 \pm 0.8$ \\
$\mathrm{MCH}(\mathrm{pg})$ & $16.0 \pm 0.5$ & $16.0 \pm 0.4$ \\
$\mathrm{MCHC}(\%)$ & $29.5 \pm 0.8$ & $29.3 \pm 0.9$ \\
$\mathrm{PLT}\left(\times 10^{4} / \mu \mathrm{L}\right)$ & $95 \pm 5$ & $97 \pm 13$ \\
RET $(\% \mathrm{o})$ & $27.8 \pm 4.8$ & $23.0 \pm 1.2$
\end{tabular}

Hematological parameters in blood treated with acai extract $(10 \mathrm{~g} / \mathrm{kg})$ daily for four days orally. WBC: Leukocyte content; RBC: Erythrocyte content; HGB: Hemoglobin; HCT: Hematocrit; MCV: Mean cell volume; MCH: Mean cell hemoglobin; MCHC: Mean cell hemoglobin concentration; PLT: Platelet content; RET: Reticulocytes. ${ }^{*} P<0.05$ by $t$-test.

\subsection{Acai Extract Acutely Upregulates the EPO Contents in Blood}

EPO is the principle regulator of red blood cell production [12]. In general, the Epo expression is transiently stimulated by a hypoxic condition [2]. After four days of administration of acai, the renal Epo expression showed a slight increase (Figure 1A). In this context, we performed a transient experiment, administering acai extract to mice and measuring the EPO contents in plasma $2-3 \mathrm{~h}$ after treatment. The acai treatment caused a significant increase in the plasma EPO level compared with vehicle control (Figure 1B). Furthermore, acai upregulated the Epo transcript level in the kidney compared with the control (Figure 1C). The erythropoiesis inducer roxadustat (ASP1517), which is also used to treat renal anemia, also upregulated both the EPO contents in plasma and the Epo transcript level in kidney (Figure 1B,C). In contrast to acai, the administration of C3Glc caused no significant change in either the EPO contents or the Epo level (Figure 1B,C). Furthermore, the relationship between the plasma EPO concentration and the kidney Epo transcript level was positive (Figure 1D). These results suggest that acai extract transcriptionally induced EPO production in the kidney.

A

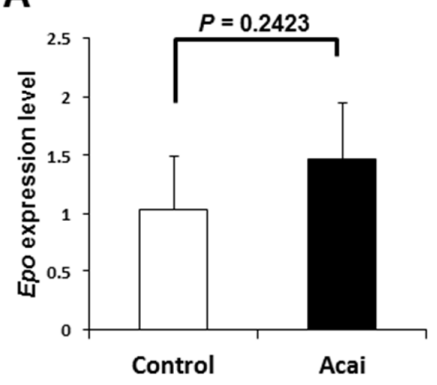

C

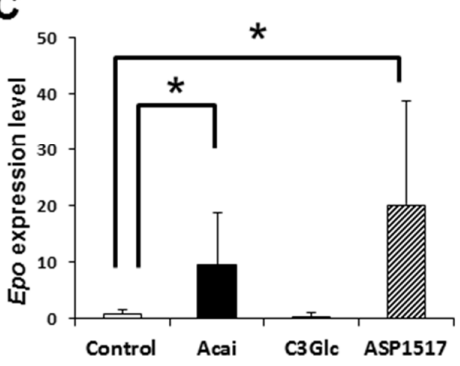

B

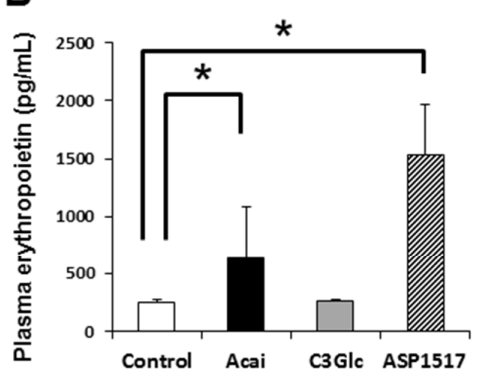

D

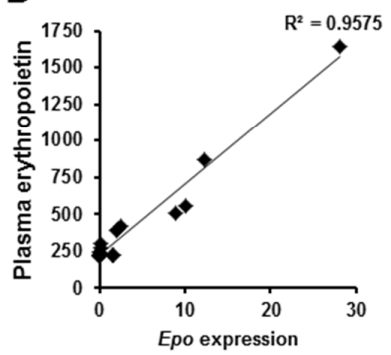

Figure 1. Acai extract upregulates both the plasma erythropoietin (EPO) concentration and kidney Epo expression. (A). The relative Epo transcript level in the kidney after the oral administration of acai extract 
(10 g/kg) dairy for four days. ${ }^{*} P<0.05$ by $t$-test. (B) The plasma EPO concentration in mice $2-3 \mathrm{~h}$ after the oral administration of acai extract $(10 \mathrm{~g} / \mathrm{kg})$, C3Glc $(50 \mathrm{mg} / \mathrm{kg})$, and ASP1517 (80 mg/kg). (C) Relative Epo transcript levels in kidney $2-3 \mathrm{~h}$ after the oral administration of acai extract $(10 \mathrm{~g} / \mathrm{kg})$, C3Glc $(50 \mathrm{mg} / \mathrm{kg})$, and ASP1517 (80 mg/kg). (D) Relationship between the plasma EPO concentration and Epo transcription in kidney. Error bars indicate the standard deviation. ${ }^{*} P<0.05$ by an ANOVA/Tukey's test.

\subsection{Acai Extract Induces a Renal Hypoxic Condition}

Finally, to investigate the relationship between EPO induction and renal hypoxia under acai administration, we administered the hypoxic probe pimonidazole to mice and histologically detected renal hypoxia. By immunostaining with pimonidazole, which accumulates in hypoxic areas, acai extract was shown to induce renal hypoxia (Figure 2A). A quantitative analysis with the fluorescence intensity of pimonidazole staining showed that acai created a significantly larger hypoxic area than was seen in the controls (Figure 2B,C). Furthermore, acai induced renal hypoxia mainly at the corticomedullary junction where erythropoietin is produced (Figure 2A,B). Along with hypoxia induction, acai also increased the expression of Vegfa, which located downstream of HIF, in the kidney (Figure 2D). These results suggest that renal erythropoietin production caused by acai depends on the hypoxic reaction in the kidney.

A

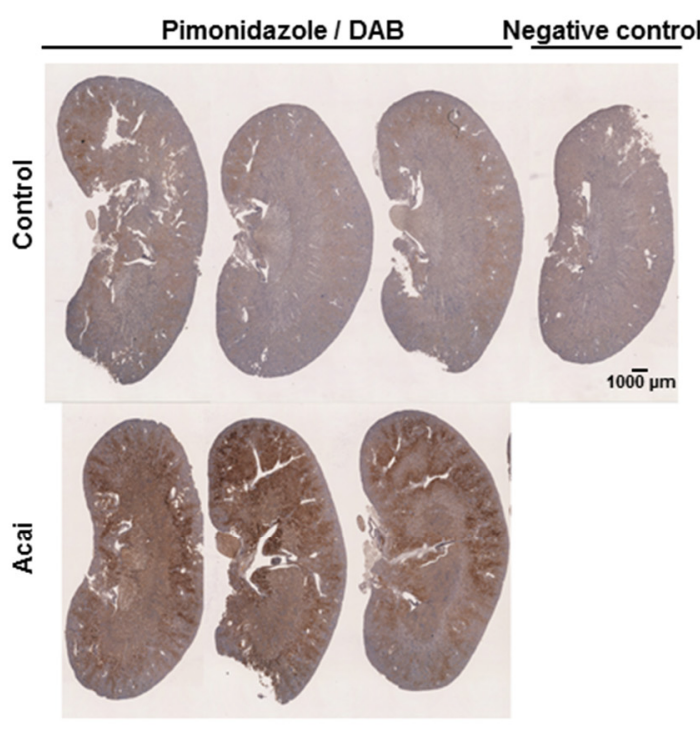

B

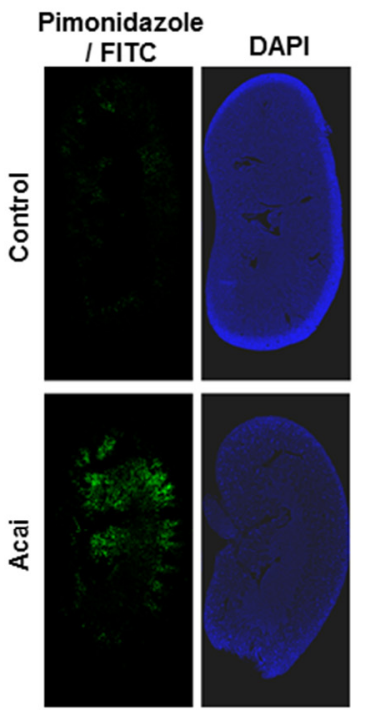

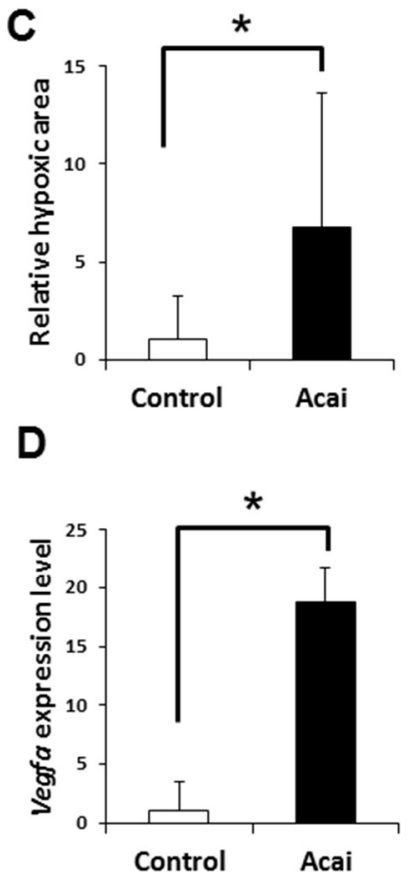

Figure 2. Acai extract induces a hypoxic reaction in kidney. (A-C) The pimonidazole-positive hypoxic area in kidney sections $2-3 \mathrm{~h}$ after the oral administration of acai extract $(10 \mathrm{~g} / \mathrm{kg})$ was detected by $3,3^{\prime}$-diaminobenzidine (A) and fluorescein isothiocyanate (B,C). (D) Relative Vegfa transcript level in the kidney $2-3 \mathrm{~h}$ after acai extract. Scale bar denotes $1 \mathrm{~mm}$. Error bar indicates the standard deviation. ${ }^{*} P<0.05$ by $t$-test.

\section{Discussion}

Since EPO, a hematopoietic hormone that controls erythropoiesis, is produced in response to tissue hypoxia, athletes often incorporate high-altitude training. The induction of EPO expression mainly involves the transcription factor HIF induced by hypoxia [3]. Under hypoxic conditions, degradation of HIF is inhibited by ubiquitination due to the suppression of proline hydroxylase, thereby promoting hematopoiesis [3]. ASP1517 induces the production of erythrocytes via the prevention of HIF degradation by inhibiting the proline hydroxylase [13]. Actually, the remarkable induction of renal hypoxia by acai suggests the HIF-mediated Epo and Vegfa upregulation (Figures 1 and 2). 
In our study, acai administration did not increase RET, which is in contrast to the increases it induced in erythropoietin and HCT (Table 2). Testosterone supplementation improved anemia in aged mice without increasing the number of reticulocytes, suggesting the contributions of an increase in erythrocyte-related genes in spleen and the normalization of iron homeostasis [14]. Since acai contains a large amount of iron, it can also increase the ferritin and iron contents, leading to iron-related hematopoiesis. As EPO is transiently induced by hypoxic conditions [2], the upregulation of EPO by acai may affect acute erythropoiesis. These findings suggest that, in contrast to the HIF-mediated erythropoiesis mechanism of ASP1517, acai may exert multiple hematopoietic mechanisms. Since the combination of EPO-stimulating and iron agents is an important anemia management strategy for patients undergoing hemodialysis [15], acai has potential applications in therapy for various types of anemia. We need to analyze the mechanisms underlying the hematopoietic effect of acai more strictly in future studies.

Acai contains large amounts of iron, various polyphenols, and long-chain fatty acids, such as oleate, palmitate and linoleate (Table 1), suggesting various beneficial effects for anemia. The monounsaturated oleic acid depresses the cytokine expression in vitro [16]. Stoner et al. reported that acai reduced the serum IL-5 and IL-8 levels in rats [17]. Anemia in the elderly population is caused by the increased expression of proinflammatory cytokines [18]. Acai may protect against anemia by reducing the levels of inflammatory cytokines increased by aging and various stressors. Furthermore, acai treatment attenuated renal ischemia/reperfusion injury via protection against renal oxidative stress in diabetic and spontaneously hypertensive rats $[19,20]$. In a rat study, acai treatment significantly decreased the 8-isoprostane immunostaining level and thiobarbituric acid reactive substances level in the kidney [20], suggesting the transition from an oxidative to a reductive condition in the kidney. These findings show that acai induces erythropoietic action via an altered redox status in the kidney. Mitochondrial angiotensin II receptors regulate oxygen consumption in kidney mitochondria [21], suggesting a deep association with the renal status and oxygen consumption. Hernandez-Vargas et al. reported that the suppressors of cytokine signaling (SOCS) family negatively regulated the angiotensin II-activated signal pathway, including JNK, resulting in a decreased renal oxygen consumption [22]. AICAR, an AMPK activator, decreased the renal oxygen consumption via the modulation of SOCS1 [23]. In this context, acai may inhibit the SOCS family, leading to the activation of the angiotensin II-mediated pathway associated with increased oxygen consumption and hypoxia in the kidney.

Polyphenols protect against reactive oxygen species-induced hemolysis via increased red blood cell integrity associated with the inhibition of lipid peroxidation [24-27]. Similarly, red cabbage extracts rich in anthocyanins rescue oxidative hemolysis in streptozotocin-induced diabetes [28]. Anthocyanins also exert antisickling activity by stabilizing red blood cells and their membranes and inhibiting polymerization on hemoglobin S [29,30]. However, C3Glc alone did not alter the erythropoietin or Epo levels (Figure 2), suggesting that not only polyphenols but also iron and fatty acids of acai contribute to erythropoiesis.

Acai showed no toxicity in experimental models [31-36] nor any significant differences in the body weight or food consumption $[17,31,32,36]$, suggesting potential applications in the prevention of various disease. Conversely, Mn, which is abundant in acai, suppresses Fe absorption, suggesting a risk for anemia [37]. The kidneys are prone to hypoxia because of their high energy consumption [38]. Chronic renal hypoxia is a final common pathway to end-stage renal failure, resulting in an irreversible decline in the renal function $[39,40]$. In a study of hypertensive rats, acai treatment for 45 days decreased the creatinine contents in the serum and urine, suggesting a protective effect on the kidney [20]. Since we only performed the acai trials for up to four days, a more detailed evaluation of the effects of longer-term treatment on the hematopoietic activity and renal function is needed. EPO formulations are presently banned as a doping substance. The erythropoietic mechanism of acai via EPO must be further clarified, and its use in sports needs to be carefully discussed.

In summary, acai induces an erythropoietic effect associated with renal hypoxia. These findings provide valuable insight into the potential utility of acai for future research on hematopoiesis in humans. 
Author Contributions: S.S., T.T., and T.S. designed the study; S.S. and T.S. wrote the manuscript; S.S., T.T., M.J.V.Y., and Y.O. performed the experiments; S.S. analyzed the data; T.S. edited the article; and T.S. coordinated and directed the project. All authors have read and agreed to the published version of the manuscript.

Funding: This research was funded by FRUTA FRUTA, Inc.

Conflicts of Interest: This does not alter the authors' adherence to all Nutrients policies on sharing data and materials.

\section{References}

1. Zanjani, E.D.; Ascensao, J.L.; McGlave, P.B.; Banisadre, M.; Ash, R.C. Studies on the liver to kidney switch of erythropoietin production. J. Clin. Investig. 1981, 67, 1183-1188. [CrossRef] [PubMed]

2. Fandrey, J. Oxygen-dependent and tissue-specific regulation of erythropoietin gene expression. Am. J. Physiol. Regul. Integr. Comp. Physiol. 2004, 286, R977-R988. [CrossRef] [PubMed]

3. Wenger, R.H.; Hoogewijs, D. Regulated oxygen sensing by protein hydroxylation in renal erythropoietin-producing cells. Am. J. Physiol. Renal. Physiol. 2010, 298, F1287-F1296. [CrossRef] [PubMed]

4. Schauss, A.G.; Wu, X.; Prior, R.L.; Ou, B.; Huang, D.; Owens, J.; Agarwal, A.; Jensen, G.S.; Hart, A.N.; Shanbrom, E. Antioxidant capacity and other bioactivities of the freeze-dried Amazonian palm berry, Euterpe oleraceae mart. (acai). J. Agric. Food Chem. 2006, 54, 8604-8610. [CrossRef] [PubMed]

5. Zapata-Sudo, G.; da Silva, J.S.; Pereira, S.L.; Souza, P.J.; de Moura, R.S.; Sudo, R.T. Oral treatment with Euterpe oleracea Mart. (acai) extract improves cardiac dysfunction and exercise intolerance in rats subjected to myocardial infarction. BMC Complement. Altern. Med. 2014, 14, 227. [CrossRef]

6. de Oliveira, P.R.; da Costa, C.A.; de Bem, G.F.; Cordeiro, V.S.; Santos, I.B.; de Carvalho, L.C.; da Conceicao, E.P.; Lisboa, P.C.; Ognibene, D.T.; Sousa, P.J.; et al. Euterpe oleracea Mart.-Derived Polyphenols Protect Mice from Diet-Induced Obesity and Fatty Liver by Regulating Hepatic Lipogenesis and Cholesterol Excretion. PLoS ONE 2015, 10, e0143721. [CrossRef]

7. Pereira, R.R.; de Abreu, I.C.; Guerra, J.F.; Lage, N.N.; Lopes, J.M.; Silva, M.; de Lima, W.G.; Silva, M.E.; Pedrosa, M.L. Acai (Euterpe oleracea Mart.) Upregulates Paraoxonase 1 Gene Expression and Activity with Concomitant Reduction of Hepatic Steatosis in High-Fat Diet-Fed Rats. Oxid Med. Cell Longev. 2016, 2016, 8379105. [CrossRef]

8. de Souza Machado, F.; Kuo, J.; Wohlenberg, M.F.; da Rocha Frusciante, M.; Freitas, M.; Oliveira, A.S.; Andrade, R.B.; Wannmacher, C.M.; Dani, C.; Funchal, C. Subchronic treatment with acai frozen pulp prevents the brain oxidative damage in rats with acute liver failure. Metab. Brain Dis. 2016, 31, 1427-1434. [CrossRef]

9. Poulose, S.M.; Bielinski, D.F.; Carey, A.; Schauss, A.G.; Shukitt-Hale, B. Modulation of oxidative stress, inflammation, autophagy and expression of Nrf2 in hippocampus and frontal cortex of rats fed with acai-enriched diets. Nutr. Neurosci. 2017, 20, 305-315. [CrossRef]

10. Martins, I.; Borges, N.A.; Stenvinkel, P.; Lindholm, B.; Rogez, H.; Pinheiro, M.C.N.; Nascimento, J.L.M.; Mafra, D. The value of the Brazilian acai fruit as a therapeutic nutritional strategy for chronic kidney disease patients. Int. Urol. Nephrol. 2018, 50, 2207-2220. [CrossRef]

11. Souma, T.; Nezu, M.; Nakano, D.; Yamazaki, S.; Hirano, I.; Sekine, H.; Dan, T.; Takeda, K.; Fong, G.H.; Nishiyama, A.; et al. Erythropoietin Synthesis in Renal Myofibroblasts Is Restored by Activation of Hypoxia Signaling. J. Am. Soc. Nephrol. 2016, 27, 428-438. [CrossRef] [PubMed]

12. Jelkmann, W. Erythropoietin: Structure, control of production, and function. Physiol. Rev. 1992, 72, 449-489. [CrossRef] [PubMed]

13. Provenzano, R.; Besarab, A.; Sun, C.H.; Diamond, S.A.; Durham, J.H.; Cangiano, J.L.; Aiello, J.R.; Novak, J.E.; Lee, T.; Leong, R.; et al. Oral Hypoxia-Inducible Factor Prolyl Hydroxylase Inhibitor Roxadustat (FG-4592) for the Treatment of Anemia in Patients with CKD. Clin. J. Am. Soc. Nephrol. 2016, 11, 982-991. [CrossRef] [PubMed]

14. Guo, W.; Li, M.; Bhasin, S. Testosterone supplementation improves anemia in aging male mice. J. Gerontol. A Biol. Sci. Med. Sci. 2014, 69, 505-513. [CrossRef] [PubMed]

15. Fishbane, S.; Shah, H.H. Ferric pyrophosphate citrate as an iron replacement agent for patients receiving hemodialysis. Hemodial. Int. 2017, 21 (Suppl. 1), S104-S109. [CrossRef] [PubMed] 
16. Verlengia, R.; Gorjao, R.; Kanunfre, C.C.; Bordin, S.; de Lima, T.M.; Curi, R. Effect of arachidonic acid on proliferation, cytokines production and pleiotropic genes expression in Jurkat cells-A comparison with oleic acid. Life Sci. 2003, 73, 2939-2951. [CrossRef]

17. Stoner, G.D.; Wang, L.S.; Seguin, C.; Rocha, C.; Stoner, K.; Chiu, S.; Kinghorn, A.D. Multiple berry types prevent N-nitrosomethylbenzylamine-induced esophageal cancer in rats. Pharm. Res. 2010, 27, 1138-1145. [CrossRef]

18. Balducci, L. Anemia, fatigue and aging. Transfus. Clin. Biol. 2010, 17, 375-381. [CrossRef]

19. El Morsy, E.M.; Ahmed, M.A.; Ahmed, A.A. Attenuation of renal ischemia/reperfusion injury by acai extract preconditioning in a rat model. Life Sci. 2015, 123, 35-42. [CrossRef]

20. da Silva Cristino Cordeiro, V.; de Bem, G.F.; da Costa, C.A.; Santos, I.B.; de Carvalho, L.; Ognibene, D.T.; da Rocha, A.P.M.; de Carvalho, J.J.; de Moura, R.S.; Resende, A.C. Euterpe oleracea Mart. seed extract protects against renal injury in diabetic and spontaneously hypertensive rats: Role of inflammation and oxidative stress. Eur. J. Nutr. 2018, 57, 817-832. [CrossRef]

21. Friederich-Persson, M.; Persson, P. Mitochondrial angiotensin II receptors regulate oxygen consumption in kidney mitochondria from healthy and type 1 diabetic rats. Am. J. Physiol. Renal. Physiol. 2020. [CrossRef]

22. Hernandez-Vargas, P.; Lopez-Franco, O.; Sanjuan, G.; Ruperez, M.; Ortiz-Munoz, G.; Suzuki, Y.; Aguado-Roncero, P.; Perez-Tejerizo, G.; Blanco, J.; Egido, J.; et al. Suppressors of cytokine signaling regulate angiotensin II-activated Janus kinase-signal transducers and activators of transcription pathway in renal cells. J. Am. Soc. Nephrol. 2005, 16, 1673-1683. [CrossRef] [PubMed]

23. Tsogbadrakh, B.; Ryu, H.; Ju, K.D.; Lee, J.; Yun, S.; Yu, K.S.; Kim, H.J.; Ahn, C.; Oh, K.H. AICAR, an AMPK activator, protects against cisplatin-induced acute kidney injury through the JAK/STAT/SOCS pathway. Biochem. Biophys. Res. Commun. 2019, 509, 680-686. [CrossRef] [PubMed]

24. Youdim, K.A.; Shukitt-Hale, B.; MacKinnon, S.; Kalt, W.; Joseph, J.A. Polyphenolics enhance red blood cell resistance to oxidative stress: In vitro and in vivo. Biochim. Biophys. Acta 2000, 1523, 117-122. [CrossRef]

25. Nabavi, S.M.; Nabavi, S.F.; Setzer, W.N.; Alinezhad, H.; Zare, M.; Naqinezhad, A. Interaction of different extracts of Primula heterochroma Stapf. with red blood cell membrane lipids and proteins: Antioxidant and antihemolytic effects. J. Diet Suppl. 2012, 9, 285-292. [CrossRef] [PubMed]

26. Phrueksanan, W.; Yibchok-anun, S.; Adisakwattana, S. Protection of Clitoria ternatea flower petal extract against free radical-induced hemolysis and oxidative damage in canine erythrocytes. Res. Vet. Sci. 2014, 97, 357-363. [CrossRef] [PubMed]

27. Tedesco, I.; Moccia, S.; Volpe, S.; Alfieri, G.; Strollo, D.; Bilotto, S.; Spagnuolo, C.; Di Renzo, M.; Aquino, R.P.; Russo, G.L. Red wine activates plasma membrane redox system in human erythrocytes. Free Radic. Res. 2016, 50, 557-569. [CrossRef]

28. Buko, V.; Zavodnik, I.; Kanuka, O.; Belonovskaya, E.; Naruta, E.; Lukivskaya, O.; Kirko, S.; Budryn, G.; Zyzelewicz, D.; Oracz, J.; et al. Antidiabetic effects and erythrocyte stabilization by red cabbage extract in streptozotocin-treated rats. Food Funct. 2018, 9, 1850-1863. [CrossRef]

29. Mpiana, P.T.; Mudogo, V.; Tshibangu, D.S.; Kitwa, E.K.; Kanangila, A.B.; Lumbu, J.B.; Ngbolua, K.N.; Atibu, E.K.; Kakule, M.K. Antisickling activity of anthocyanins from Bombax pentadrum, Ficus capensis and Ziziphus mucronata: Photodegradation effect. J. Ethnopharmacol 2008, 120, 413-418. [CrossRef]

30. Mpiana, P.T.; Ngbolua, K.N.; Bokota, M.T.; Kasonga, T.K.; Atibu, E.K.; Tshibangu, D.S.; Mudogo, V. In vitro effects of anthocyanin extracts from Justicia secunda Vahl on the solubility of haemoglobin $\mathrm{S}$ and membrane stability of sickle erythrocytes. Blood Transfus. 2010, 8, 248-254.

31. Fragoso, M.F.; Prado, M.G.; Barbosa, L.; Rocha, N.S.; Barbisan, L.F. Inhibition of mouse urinary bladder carcinogenesis by acai fruit (Euterpe oleraceae Martius) intake. Plant Foods Hum. Nutr. 2012, 67, 235-241. [CrossRef] [PubMed]

32. Fragoso, M.F.; Romualdo, G.R.; Ribeiro, D.A.; Barbisan, L.F. Acai (Euterpe oleracea Mart.) feeding attenuates dimethylhydrazine-induced rat colon carcinogenesis. Food Chem. Toxicol. 2013, 58, 68-76. [CrossRef]

33. Monge-Fuentes, V.; Muehlmann, L.A.; Longo, J.P.; Silva, J.R.; Fascineli, M.L.; de Souza, P.; Faria, F.; Degterev, I.A.; Rodriguez, A.; Carneiro, F.P.; et al. Photodynamic therapy mediated by acai oil (Euterpe oleracea Martius) in nanoemulsion: A potential treatment for melanoma. J. Photochem. Photobiol. B 2017, 166, 301-310. [CrossRef] [PubMed] 
34. Ribeiro, J.C.; Antunes, L.M.; Aissa, A.F.; Darin, J.D.; De Rosso, V.V.; Mercadante, A.Z.; de Bianchi, M.L. Evaluation of the genotoxic and antigenotoxic effects after acute and subacute treatments with acai pulp (Euterpe oleracea Mart.) on mice using the erythrocytes micronucleus test and the comet assay. Mutat. Res. 2010, 695, 22-28. [CrossRef] [PubMed]

35. Marques, E.S.; Froder, J.G.; Carvalho, J.C.; Rosa, P.C.; Perazzo, F.F.; Maistro, E.L. Evaluation of the genotoxicity of Euterpe oleraceae Mart. (Arecaceae) fruit oil (acai), in mammalian cells in vivo. Food Chem. Toxicol. 2016, 93, 13-19. [CrossRef] [PubMed]

36. Schauss, A.G.; Clewell, A.; Balogh, L.; Szakonyi, I.P.; Financsek, I.; Horvath, J.; Thuroczy, J.; Beres, E.; Vertesi, A.; Hirka, G. Safety evaluation of an acai-fortified fruit and berry functional juice beverage (MonaVie Active(R)). Toxicology 2010, 278, 46-54. [CrossRef] [PubMed]

37. da Silva Santos, V.; de Almeida Teixeira, G.H.; Barbosa, F., Jr. Acai (Euterpe oleracea Mart.): A tropical fruit with high levels of essential minerals-especially manganese-and its contribution as a source of natural mineral supplementation. J. Toxicol. Environ. Health A 2014, 77, 80-89. [CrossRef]

38. Gallagher, D.; Belmonte, D.; Deurenberg, P.; Wang, Z.; Krasnow, N.; Pi-Sunyer, F.X.; Heymsfield, S.B. Organ-tissue mass measurement allows modeling of REE and metabolically active tissue mass. Am. J. Physiol. 1998, 275, E249-E258. [CrossRef]

39. Mimura, I.; Nangaku, M. The suffocating kidney: Tubulointerstitial hypoxia in end-stage renal disease. Nat. Rev. Nephrol. 2010, 6, 667-678. [CrossRef]

40. Nangaku, M. Chronic hypoxia and tubulointerstitial injury: A final common pathway to end-stage renal failure. J. Am. Soc. Nephrol. 2006, 17, 17-25. [CrossRef]

(C) 2020 by the authors. Licensee MDPI, Basel, Switzerland. This article is an open access article distributed under the terms and conditions of the Creative Commons Attribution (CC BY) license (http://creativecommons.org/licenses/by/4.0/). 